\title{
From the Poet to the Pedant: Models and Counter- Models of Classical Learning in the Renaissance
}

\author{
Nicholas Albanese \\ Texas Christian University \\ n.albanese@tcu.edu \\ https://dx.doi.org.10.12795/futhark.2016.il I.0I
}

Fecha de recepción: 15.03 .2016

Fecha de aceptación: 20.05.2016

\begin{abstract}
The figure of the pedante and its presence in Renaissance culture has been observed and analyzed principally by scholars and historians of $16^{\text {th }}$ century theatrical production, who have delineated the contours of the largely unified character in terms of its physical and performative characteristics on the stage. After Arturo Graf's discussion of the pedant in Renaissance comedy over 130 years ago, it is only in more recent times that theater scholars have turned their interest towards the character even though the wider cultural context and relevance of its appearance outside of the theater has not been adequately addressed. Nevertheless, the figure of the pedant can be seen as a site in which oppositional trends emerge for the development of the educational and cultural project of the age. In this paper I will discuss the figure of the pedant in relation to the fundamental idea of the humanist and its social role as had been developed by authors in the $14^{\text {th }}$ and $15^{\text {th }}$ centuries, beginning with the exemplar established by the recognized padre dell' Umanesimo, Francesco Petrarca. The appearance and development of this character not only underscore a change in cultural and literary models, but they also become keys for understanding crucial socio-economic shifts of the Cinquecento.
\end{abstract}

Key words: Renaissance comedy, pedant, Petrarca, Cinquecento.

\section{Desde el poeta al pedante: modelos y contra-modelos del saber clásico en el Renacimiento}

Resumen: La figura del pedante y su presencia en la cultura renacentista ha sido observada y analizada sobre todo por los especialistas e historiadores que estudian la producción teatral del siglos XVI, quienes han perfilado los contornos de un personaje cuyas características físicas y teatrales han sido ampliamente unificadas. 
Tras el estudio de Arturo Graf sobre el pedante en la comedia renacentista, hace más de 130 años, los especialistas vuelven a interesarse por este personaje dramático. En cualquier caso, la figura del pedante puede considerarse como un lugar del que emergen tendencias opuestas para el desarrollo del proyecto cultural y educativo de la época. En este trabajo se abordará el estudio del pedante como humanista y su papel en la sociedad, tal y como los autores de los siglos XIV y XV lo concibieron, comendando por el padre dell' Umanesimo, Francesco Petrarca. La aparición y desarrrollo de este personaje no solo acentúa un cambio en los modelos culturales y literarios, sino también se convierte en la clave para comprender los principales cambios socio-económicos del Cinquecento.

Palabras clave: comedia renacentista, pedante, Petrarca, Cinquecento.

Sumario: Introduction. I. The birth of the pedant in Renaissance comedy. 2. The pedant and the false poet. 3 . The role of knowledge in humanist educational discourse. Conclusions.

\section{Introduction}

The figure of the pedant in the Renaissance holds particularly significant cultural value because of its contemporary origins and evolution that, in part, reflect the shifts and crises of the humanist movement throughout its elaboration and development from the late $14^{\text {th }}$ to the late $16^{\text {th }}$ century. While there is textual evidence that the satirical representation of the figure of the letterato had already begun being formulated, it is on the stage of comic theater in Italy where "il pedante viene in persona a far mostra di ogni ridicolaggine sua, e ad esporsi al riso e alle beffe" (the pedant appears in person to put on display all of his ridiculous behavior and to expose himself to laughter and ridicule) $)^{1}$ (Graf 1888: 198), assuming its most successful, fully-developed, and widespread portrayal as an exclusively caricatural object of contempt. Theater scholars have traced the first appearance of the pedant in Renaissance comedy to the court of Urbino in 1513 where two characters - Polinico in Cardinal Bernardo Dovizi da Bibbiena's La calandria and Ocheutico in Nicola Grasso's Eutichia - partially present just a few of the characteristic elements that would later become the trademark of the figure in comic theater. ${ }^{2}$ The first fully developed theatrical pedants, however, have been

\footnotetext{
' All English translations without a bibliographic reference are by the present author.

${ }^{2}$ Antonio Stäuble calls these two earliest incarnations of the pedant on stage 'protopedanti' (protopedants) (17). The pedant character, Messer Piero, in Glingannati, authored by the Accademia degli Intronati in 153I and performed in Siena in February of 1532, has been disregarded by critics as one of the earliest pedants on the stage due to its marginal role in the play and because the character may have 
widely recognized in the characters of Prudenzio in Francesco Belo's II pedante in 1529 and the pedant in Pietro Aretino's II marescalco of 1533, both of which present the traits of the familiar character type that is ridiculed in numerous successive plays of the genre. In fact, the pedant, which figures prominently in theatrical pieces after 1533, will please audiences throughout the arc of production of Renaissance comedy, whose endpoint is almost unanimously seen by scholars in Giordano Bruno's Candelaio, published in Paris in 1582. Manfurio, one of the protagonists of the Nolan's play, has been identified as the "pedante più perfetto che sia sul teatro" (most perfect pedant ever on the stage) (Graf I888: 206) whose notoriety is owed to his "extraordinary personality" (Hodgart 1997: 97).

From Graf's initial study to more contemporary analyses such as Cairns' (1985), Stäuble's (199I), and Hodgart's (1997), scholars have unanimously identified in the pedant a theatrical character that was born during the Renaissance as it has no known predecessor in classical comedy. ${ }^{3}$ While the figure of the pedante has been analyzed principally by theater historians who have delineated the contours of the largely unified character in terms of its physical and performative characteristics in comedies of the Cinquecento, ${ }^{4}$ there has been relatively little critical attention paid to the dynamics that contributed to its birth in the context of Renaissance Humanism. Nevertheless, some of the characteristic connotations of the pedant are the character's erudition and his use of classical Latin references. Thus, it might be argued that the seed of pedantry is an intrinsic part of the movement with its emphasis on textual literacy and philological knowledge of Latin auctores.

Cultural historians have long characterized the early $16^{\text {th }}$ century as the beginning of the period of fracture, mutation, and ultimately decline of the classical moment of the Renaissance. The ephemeral foundations of the psychological certainties of dignitas hominis and harmonia mundi as developed by thinkers such as Pico della Mirandola and Marsilio Ficino were being undermined not only by historical and social forces but also by the advancement of empirical understanding and discovery. As part of the critique of classical humanism, which art historians

been added at a later date, based on Aretino's character, sometime before the publication of the text in Venice in 1537.

3 Theater scholars discount the pedagogue Lydus in the Bacchides by Plautus as a possible model since he is not ridiculed for his profession nor for his learning.

${ }^{4}$ Cfr. STÄUBLE, Antonio, «Parlar per lettera»: II pedante nella commedia del Cinquecento e altri saggi sul teatro rinascimentale, Rome: Bulzoni Editore, I99I; GRAF, Arturo, "I pedanti" in Attraverso il Cinquecento, Torino: Loescher, 1888, pp. I7I-2I3; HODGART, A. Buono, Giordano Bruno's The Candle-Bearer: An Enigmatic Renaissance Play, Lewiston/Queenston/Lampeter: The Edwin Mellen Press, 1997; and CAIRNS Christopher, Pietro Aretino and the Republic of Venice, Firenze: Olschki, 1985 chapter 3, "The Marescalco and the Italian Renaissance Pedant", pp. 49-68. 
have seen as one of the foundational causes for the aesthetic crisis in the visual arts, ${ }^{5}$ the figure of the man of classical lettres and that of the humanist pedagogue becomes, in fact, the site in which oppositional trends emerge within the contours of Renaissance Humanism. It is within this context that I will here discuss the conception of the pedant in relation to the fundamental idea of the humanist and its social role as developed by writers in the $14^{\text {th }}$ and $15^{\text {th }}$ centuries, beginning with the recognized padre dell'Umanesimo, Francesco Petrarca. The appearance and development of the pedant as a character underscore important debates on the role of knowledge and poetry in the Cinquecento and thus become keys for understanding crucial cultural and socio-economic shifts that characterize the period.

\section{The birth of the pedant in Renaissance comedy}

The features of the pedant appear in dozens of comedies throughout the Renaissance, ${ }^{6}$ from Francesco Belo's II pedante (1529) to Giovanni della Porta's II moro (published in 1607), and by the end of the $16^{\text {th }}$ century the character developed into a type with fixed traits whose afterlife has been discerned in the maschera of Dottor Balanzon of the commedia dell'arte (Campanelli 1965: 42-45). The apex of this development is often identified by theater scholars in Bruno's Manfurio, who comes to represent the most exaggeratedly creative example of the figure. Manfurio, in fact, displays those characteristics that had come to be most closely associated with the character type, especially the ostentatious and affected display of (faulty) Latin erudition expressed in a hybrid language as "original as it is incomprehensible" (Hodgart 1997: 97) that makes the character, who is largely disconnected from the play's storyline, an object of derision as well as of pranks (beffe) with often violent consequences. While there are differences among the specific instances of the character, it is nevertheless possible to identify common threads and to describe the features for which the pedant is mercilessly mocked on the stage. Typological traits include those relative to his role as a pedagogical maestro, such as the severity and violence of the instructive methodology, the

\footnotetext{
${ }^{5}$ Art historians such as Walter Friedlaender and Arnold Hauser theorized this shift in visual aesthetics in connection with the historical upheaval of the period almost a century ago using the term 'mannerism'. While the term and the connection have been somewhat discredited by John Shearman's 1967 study titled Mannerism, there has recently been a re-evaluation of the mannerist theoretical foundation. See, in particular: HANSEN, Morten. "After the Veronica: Crisis and the Ars sacra of Polidoro da Caravaggio and Pontormo." I Tatti Studies in the Italian Renaissance, vol. 17, no. 2, 2014, Pp. 325-367.

${ }^{6}$ While an exhaustive list of pedantic characters in Italian Renaissance comedy has not been compiled, Stäuble's list (II-13) includes more than 45 comedies.
} 
tendency towards pederasty, and the total immersion in and dedication to the classical erudition as well as the unkempt nature of his physical appearance (Cairns 1985: 50). Various cultural and linguistic elements are also the object of derision, such as the caricatural imitation of the Petrarchan love lyric often written by the pedantic character and the use of a macaronic idiom that mixes the volgare with Latin. This "ibrido miscuglio di latino e di italiano" (hybrid mixture of Latin and Italian) (Stäuble 1991: 15), which is seen as the defining feature of the character type, includes the frequent interjection of citations from classical authors, often misquoted and/or used inappropriately for comic effect, that reveals a reduction of humanist learning into "sterile dogmatism" (Hodgart 1997: 102) with no practical connection to the real world. The linguistic confusion between the pedant and other characters that results often leads to more than just logomachic performance; it places the false scholar in situations that lead to his physical and/or emotional abuse, or to his being duped by the beffe of others. ${ }^{7}$

What emerges from the corpus of farcical comic production involving the figure of the pedant from 1529 forward is the critique of the fundamental disconnect between the pedant's "concezione sclerotizzato della cultura umanistica, avulsa della realtà e divenuta puro gioco formale" (fossilized conception of humanist culture, detached from reality and turned into a purely formal exercise) (Stäuble 1991: 115), which translates as his inability to adequately understand and interact with the world as reflected on stage. In fact, the pedant's immersion into the world of Latin culture, as Patrizia De Capitani has observed in her reading of Nicolò Franco's I piacevoli dialoghi (1539), as a means of avoiding the challenges of the period rather than meeting them, as does the true letterato (De Capitani 1992: 199). It is this disconnect and overall degradation of humanist cultural that seems to provide an indication of the origins of the figure of the pedant. While most every other character type of Renaissance comic theater in Italy is derived from the comedies of Plautus and Terenzius, the pedant, as mentioned above, has no apparent model in the classical tradition (Stäuble 1991: 14; Cairns 1985: 50), and thus there would seem to be a particularly important connection between the theatrical figure and the historical moment. While attempts to associate theatrical pedants with real-life models remain largely a question of speculation, they suggest that the object of the satire could instead be a specific type of intellectual figure rather than classical learning in and of itself, one employed as a maestro whose preparation is insufficient and whose projection of erudition consists of the uncritical and erroneous repetition of memorized Latin maxims. Much like the anticlerical satire in the novelistic tradition, the critique of notionism and superficial

\footnotetext{
7 For further discussion of the features as well as of the comic categories relative to the theatrical character, cfr. the first two chapters of Stäuble's (I99I) study. 
knowledge takes aim at the exploitation of an ideal - in this case cultural rather than religious - by those who do not have a true vocation but instead seek a profession that would give them prestige and a life of relative ease beyond their station and their abilities.

The appearance of the pedant on stage, then, has been associated with the cultural milieu of the early $16^{\text {th }}$ century along with the events that marked the period from a political, social, and psychological point of view. Studies on the character, in fact, suggest direct links between historical events and the development of the theatrical character type. Stäuble gives importance to the fact that its eruption on the stage occurs in the years immediately following the Sack of Rome in 1527 (Stäuble 1991: 14), for example, and Cairns speculates that the characters in both Belo and Aretino were independently inspired by the works of Erasmus (Cairns 1985: 64-65). Nevertheless, some of the negative connotations associated with the figure date to at least several years earlier than its affirmation on stage in 1529 and seem to be associated to the conception of the humanist scholar. In addition to the transformative events, inventions, discoveries, and cultural upheavals of the age - from the printing press to the Sack of Rome, from the Protestant Reformation to Copernicus' heliocentric theory - the development of the pedant also implicates aspects of a cultural critique that is embedded by writers in the fortunes and misfortunes of the character on stage. Theater scholars such as Hodgart and Stäuble have noted that characteristics which later come to define the character of the pedant in theater begin to appear in the Quattrocento in poetry and in novelle. Such a development might be read as the symptom of fractures in the cultural landscape that appear in the $15^{\text {th }}$ century and whose seeds were already intrinsic to the humanist enterprise with its stress on classical learning and philology when disassociated from active life. In Bibbiena's brief satirical representation of the pedagogue in La calandria in 1513 , for example, aspects of the pedant emerge as a critique of the humanist figure. Going back even further, Raffaele Nigro has noted in the burlesque poetry of Burchiello (pseudonym of Domenico di Giovanni, |404-|449) "una lotta alla cultura dominante ed esaltazione dell'innatismo" (a struggle against the dominant culture and the exaltation of innatism) (Nigro 2002: xvi) that, even while reflecting the humble social status of the author, seems to represent a precocious fracture of the cultural landscape through the implicit critique of the educated elite, both ecclesiastical and otherwise. Such instances of overlapping features between the humanist and the pedant allow for an analysis of the character of the pedante within the larger debate on the role of the knowledge, education, and writing that becomes apparent in the works of poets and humanists throughout the arch of Renaissance. 


\section{The pedant and the false poet}

Within the literary canon of the first decades of the Cinquecento, and several years before the appearance of the stage character in 1529, there registers some of the earliest examples of the parodic representation of the pedante as a critique of aspects of the cultural establishment in two satirical works written between I524 and 1525: Ludovico Ariosto's Satire and Francesco Berni's II dialogo contra i poeti. In the sixth of Ariosto's satires, written in the terza rima sometime between I 524 and 1525 and addressed to Pietro Bembo, to whom the author asks advice in choosing a maestro for his 15-year-old son, Ariosto is heavily critical of learning if not supported by virtue and goodness. In the first satire ever produced in the vernacular, the man of learning, whom he calls umanista - a word that here appears for the first time in Italian literature (Ariosto; Wiggins 1976: 166) - is in Ariosto's conception rarely equipped with moral virtue, which is prioritized above knowledge.

Dottrina abbia e bontà, ma principale

sia la bontà: che, non vi essendo questa,

né molto quella alla mia stima vale.

So ben che la dottrina fia più presta

a lasciarsi trovar che la bontade:

sì mal l'una ne l'altra oggi s'insesta. (vv. 16-2I)

Make sure he is learned and good, but first of all good, for without goodness learning, in my opinion, is worth little. I know indeed that learning is much more quickly to be found than goodness, since these days the one agrees so poorly with the other. (Ariosto; Wiggins 1976: I52-153)

This mutual exclusivity between dottrina and bontade as expressed in the satire is based upon three disastrous defects attributed to the man of classical letters: homosexuality, the lack of Christian faith, and deception evidenced by the changing of baptismal names into its perverted Latin form, all of which would later become part of the pedantic character's persona in theatrical representations of the figure.

Senza quel vizio son pochi umanisti che fe' a Dio forza, non che persüase, di far Gomorra e i suoi vicini tristi: (vv. $25-27)$

\section{[...]}

Et oltra questa nota, il peccadiglio

di Spagna gli dànno anco, che non creda

in unità del Spirto il Padre e il Figlio. (vv. $34-36$ )

\section{$[\cdots]$}


Il nome che di apostolo ti denno

d'alcun minor santo i padri, quando cristiano d'acqua, e non d'altro ti fenno, in Cosmico, in Pomponio vai mutando; altri Pietro in Pierio, altri Giovanni in lano o in lovïan va riconciando; quasi che "I nome i buon giudici inganni, e che quel meglio t'abbia a far poeta che non farà lo studio de molti anni. (vv. 58 - 66) (Ariosto; Wiggins 1976: I52-154)

Few humanists are without that vice which did not so much persuade, as forced, God to render Gomorrah and her neighbor wretched!

\section{$[\ldots]$}

And beyond this blemish, the peccadillo of Spain damns him as well, which does not concede belief in the Father, the Son, and the Holy Ghost.

\section{$[\ldots]$}

The names your fathers gave you of apostles and lesser saints, and of no one else, when they made you Christians with water, you change to Cosmicus and to Pomponius. One of you spoils Pietro with Pierius, while another ruins Giovanni with Janus or Jovian, as if names could deceive good judges and could make you better poets than years and years of labor and learning. (Ariosto; Wiggins 1976: I53-I55)

Furthermore, Ariosto seems to indicate that too much learning may be an obstacle to true faith rather than a means to enter Paradise, laying bare the fundamental question of whether intense study of Latin culture aids in divine salvation, a dilemma that was present since the earliest instances of humanist thought, most notably in Petrarch's formulation of humanist principles.

Se Nicoletto o fra Martin fan segno

d'infedele o d'eretico, ne accuso

il saper troppo, e men con lor mi sdegno:

perché, salendo lo intelletto in suso

per veder Dio, non de' parerci strano

se talor cade giù cieco e confuso. (vv. $43-48$ )

If Nicoletto and Brother Martin show signs of unbelief or heresy, I accuse their excessive knowledge and am less angry with them; when the intellect ascends on high to see God, we must not think it strange if sometimes it falls down blind and bewildered. (Ariosto; Wiggins 1976: 154-155)

While Ariosto's sixth satire, which has been characterized as an idealized autobiography expressed within "a polarity between the real and the ideal" (Ariosto; Wiggins 1976: xxi), is ostensibly a defense of poetry and of humanistic 
study in general as a worthy undertaking, the author nevertheless is severe in his condemnation of the behavior of some poets, specifically those who are also the object of Berni's attacks, as I will discuss below. The critique of poetry in the Satire must be read in the context of the author's disenchantment with the entire institution of courtly patronage and service based on his own experience with his patrons of the Este family in Ferrara, Cardinal Ippolito and Duke Alfonso. It seemingly derives, therefore, from the degradation of Latin culture, rather than from poetry as an expressive form, that resulted from its exploitation within the political dynamics of the courtly institution. The tension, therefore, exists in the work between the vocation and those who practice it, between the cultural ideal and actuation. Part of the criticism is aimed at the secularization process that developed in parallel with the educational program of the studia humanitatis of the $15^{\text {th }}$ century which represents a marked change from Petrarch's elaboration of Humanism in Christian terms. In Ariosto's construction, some negative aspects of humanist learning, in particular those that highlight the incompatibility of Latin culture with the Christian faith, are brought to bear, and thus the figure of the humanist poet risks yielding to a bestial nature deprived of the virtuous elements that had been originally espoused as the motivating force behind the recovery of classical auctores. This bestial nature that will become typically associated with the theatrical pedant might well be read as signaling shifts in the definition of the role of poets and their relationship to the social body.

Some of the same accusations are much more caustically leveled at men of letters in Berni's Dialogo contra i poeti, written at the end of 1525 and published anonymously in 1526, along with more traditional critiques such as the uselessness of poets and poetry, the privileging of the pagan world over the Christian one, the innate heretical nature of poetry, and the presumption and plagiarism of poets, to name just a few (Reynolds; Berni 1997: 149-154). However, in Berni's disputa which scholars speculate as likely having been inspired by the writings of Erasmus (Corsaro 1988: 39-43; Figorillo 2008: 78) - there is more emphasis on morality as humanist poets are strongly attacked for their 'paganesimo eretico' (Corsaro 1988: 23). Going even further than Ariosto, Berni derides the very act of poetic invention.

E' sono così fastidiosi e maladetti che credo che li farei mettere in galea a provare se è così dolce cosa a sentir cantar le sirene [...]. lo vorrei una volta che gli uscissino de finzioni e dicessino il vero de visu, che sì che uscirì loro la voglia di esser poeta e di rompere altrui la testa con li scartabelli.

Poets are so bothersome and abominable that I think I would have them put in a prison galley to experience whether it is such a sweet thing to hear the sirens sing [...]. I wish for once they would give up make-believe and tell the truth as it is, and that this way they would lose the wish to be poets and torment others with their paltry writings. (Reynolds; Berni 1997: 188-189) 
Berni, however, who delivers a "striking exposé of Roman social and cultural networks" (Reynolds 1988: 52), has in mind a clearly defined and circumscribed group of poets and a genre of poetic composition, as the reader comes to discover towards the end of the Dialogo through the words of Sanga in response to a comment made by his interlocutor Marco:

Or se' tu così matto che tu pensi ch'io chiami poeta chiunque fa versi? O ch'io metta questi uomini da bene che hai raccontato, e molti altri amici miei in conto e in dozina de poeti? lo non chiamo poeta, e non danno, se non chi fa versi solamente e tristi, e non è buono ad altro.

Now are you so crazy that you think I call poet anyone who writes verses? Or that I tar with the same brush these gentlemen you've named, and many other friends of mine, and put them in the same boat as poets? The only people I call poets, and condemn, are those who write verse only, wicked verse at that, and who are good for nothing else. (Reynolds; Berni 1997: 212-213)

The socio-cultural context as well as the poets mentioned in the Dialogo such as the humanist Pietro Alcionio who is mentioned twice in the work - seem to indicate that the poetry under attack is Latin poetry. Berni's critique evidently points to the contradictions of the culture and society of the age, with the target of the attacks, as Corsaro sustains, being the 'rapporto ipocrita tra poesia e occasione, ovverosia fra letteratura e istituzione' (hypocritical relationship between poetry and occasion, that is between literature and institution) (Corsaro 1988: II). The poets of courtly environments who profess to adhere to humanist ideals in their poetry, in reality, do not have the formation nor the ingegno necessary for poetic enterprise, and together with their powerful employers - whether popes or princes - they are condemned by Berni in his diatribe. Berni's own poetic words in reference to Michelangelo's poetry - ei dice cose, e voi dite parole (Berni; Romei 1985: 184) - seem to be a clear reflection of the invective against those who write poetry as a profession rather than as a vocation:

[...] gente immorale, ma anche e soprattutto gente che trasgredisce e fa spregio dei comandamenti di Nostro Signore perché atea e pagana, inosservante, blasfema; gente ambiziosa che fa proprio un irrazionale culto della poesia per arricchirsi a spese dei potenti. (Berni; Romei 1985: I)

$[\ldots]$ immoral people, but also and above all people who transgress and disdain the commandments of Our Lord because they are atheist and pagan, inobservant, and blasphemous; ambitious people who make an irrational cult of poetry their own in order to enrich themselves in the service of the powerful.

Berni's denunciation can be read as a defense of the humanistic program from 'false poets' that condemns those who exploit poetry as a means of personal enrichment rather than the use of knowledge in the search for truth, thereby distorting a foundational element of the humanist value system. A similar aversion 
against the cult of poetry permeates Castiglione's II libro del Cortegiano and is crucial to his disdain for what he calls "affettazione" - "un comportamento costruito, impostato senza naturalezza, lezioso, ricercato" (a constructed, counterfeited behavior, insincere and artificial) (Castiglione; Barberis 59) - that Stäuble situates "agli antipodi del nuovo ideale di 'sprezzatura' teorizzato dal Castiglione" (at the antipodes of the new ideal of 'sprezzatura' theorized by Castiglione) (Stäuble 1991: III). Such traits of affectation and commodification of knowledge of Latin authors become intrinsic to the theatrical version of the pedant in varying degree, from Belo's Prudenzio to Aretino's character in II marescalco, from Lodovico Dolce's unnamed Pedante (in II ragazzo, I54I) to Giordano Bruno's Manfurio in the Candelaio.

The existence of ambivalence as seen above in Ariosto and Berni is clear in regard to the conception of humanist learning, which had come to be associated with the production of lyric poetry following the model established by Petrarca, the widely recognized founder of the movement. Even though he was preceded by two generations of humanist practitioners, ${ }^{8}$ it was his construction of the self as a Christian ethical subject in relation to the recovery of Latin auctores that was projected both by his autobiographical writings as well as by those of $15^{\text {th }}$ century humanists. Scholars such as Aldo Bernardo and Karl Enenkel have discussed how Petrarca's Epistola posteritati (c. 1370) greatly influenced successive biographical writings of the $15^{\text {th }}$ century as well as an almost hagiographic conception of the poet laureate's model life as a "born-again ancient with Christian insight" (Bernardo 1986: 57). At stake for Petrarca in this self-representation is the delicate privileging of the writer's Christian persona over the valorization of Latin erudition for his limited contemporary audience, which would have seen even the very act of autobiographical writing in the tradition of classical authors as an impious pursuit of earthly fame. ${ }^{9}$

In presenting himself as a living exemplum for a new conception of learning as well as a new social role, Petrarca touches on many of the points that would later become fundamentally important for humanist writers of the Quattrocento: the

\footnotetext{
8 Ronald G. Witt discusses the origins of Humanism and how this characterization of Petrarch as its founder is more a question of projection. Witt sees Petrarch instead as the founder of Christian Humanism. Cfr. Chapter 6 of WITT, Ronald G., 'In the Footsteps of the Ancients': The Origins of Humanism from Lovato to Bruni. Leiden/Boston/Köln, Brill: 2000.

9 Cfr. ENENKEL, Karl, "In Search of Fame: Self-Representation in Neo-Latin Humanism” in GERSH, Stephen; ROEST, Bert (eds), Medieval and Renaissance Humanism: Rhetoric, Representation and Reform. Leiden/Boston: Brill, 2003, Pp. 93-II 3 and ENENKEL, Karl, “Modelling the Humanist: Petrarch's Letter to Posterity and Boccaccio's Biography of the Poet Laureate" in ENENKEL, Karl; DEJONG-CRANE, Betsy; LIEBREGTS, Peter (eds.), Modelling the Individual: Biography and Portrait in the Renaissance. Amsterdam/Atlanta: Rodopi, 1998, Pp. I I-49.
} 
inseparability of the study of classical literature and moral virtue; the utility of imitatio of classic texts in the search for an eloquent style capable of persuasion; and the sense of historical distance between the present world and that of classical antiquity. The apologetic tone of Petrarca's letters - which Mazzotta calls a "hermeneutics of self" (Mazzotta 1993: III) - must also be read in the context of humanist image-building in a society that as of yet had no assigned role for humanists in the institutions of cultural activity - namely universities and religious centers - which were not immediately receptive of their activity. Thus, in his Epistola posteritati, even while claiming to not understand why, Petrarca insists on having been sought out by the greatest kings of the period as a suggestion for a social model that would grant prestige and respectability to the humanist intellectual who had no other means of subsistence in the $14^{\text {th }}$ century (Enenkel 1998: 46-49).

Even though Petrarca downplays his own interest in poetry along with his own intellectual prowess and knowledge of Latin letters, these are the elements that define the humanist program right from its origins. The almost metaphysical virtues of modesty and humility projected by Petrarca, far from appearing as blatantly false the way it might to some modern readers, was an important component of the figure's viability as a cultural persona. Petrarca's synthesis of Latin culture with Christian ethics imbues the humanist conception with a doublerole that lies in both the secular and the religious spheres while providing a basis for successive strains of the project, such as the republican or civic humanism of the following century. Rather than being contradictory, the two cultures can be complementary and the study of the right classic authors - such as Cicero and Seneca, Horace and Ovid - can serve to shape the individual toward the desire to be good, which is one and the same with being good: pars est bonitatis velle bonum fieri (Petrarca; Fenzi 1999: 212). The principle precept for humanists from Petrarca forward is the relationship between literary erudition in Latin and its usefulness in influencing the will, which could only be achieved by the intellect through rigid literary preparation in Latin letters. Later humanists, in fact, recognized the vital role of education in society not as an end but instead as a vehicle whose fruition leads to the achievement of a foundational goal that can only serve as beneficial to the social makeup.

Despite a somehow fluid use of the word humanist and poet, as we have seen in Berni and Ariosto, there remains a positive exception of the figure of the poet as one who is dedicated to the study of letters and the writing of poetry with the authentic intent to participate in dialogue with the past and the future. The figure of the opportunist poets of the court attacked by Ariosto, Berni and Castiglione, however, have characteristics similar to those later ascribed to the character of the pedant in comic theater. The attacks on these false poets and the 
hypocrisy of their classical erudition in the first few decades of the Cinquecento implicitly reveal the risks of a humanist education that emphasizes philology and the writing of poetry. There is, however, little explicit reference in these satirical writings of the intrinsic dangers for the humanist poet to the pedagogical elements that become central to the theatrical character of the pedante. It is necessary to turn to $15^{\text {th }}$ century authors - Colluccio Salutati, Pier Paolo Vergerio, Leon Battista Alberti - and their discussion of education and the role of letters to identify how such debate might have informed the development of a professional category of the literate pedagogue who would later inspire the pedant in theater.

\section{The role of knowledge in humanist educational discourse}

In the decades following Petrarch's original construction of the humanist poet, through the works of figures such as Colluccio Salutati (I33|-|406), Pier Paolo Vergerio (1370-1444), and Leon Battista Alberti (1404-1472), the role of the humanist is regarded with an increasing sense of social prestige, thereby provoking more determined opposition, above all from the Church. In fact, intellectuals found themselves having to defend the humanist program from members of the clergy who were against the study of classical texts for young people, which had become the foundation of the humanist educational curriculum. In 1404, for example, Salutati responds to criticism by the Dominican Fra' Giovanni Dominici, who railed against the instruction ancient texts to impressionable minds with a great capacity for memory and an ethical formation still too unstable to digest the works of preChristian authors. In his response, Salutati argues that the artes sermocinales, just like the Christian program, seek the truth, and therefore the studia humanitatis are of fundamental importance for the faithful. Any belief that is based on faith alone is easily replaced by human reason, as the humanist affirms in his letter to the friar:

Nunc autem que sola fide tenemus talia sunt, quod ad ea naturalis ratio non pertingat, ut facile sit sola fide fundatum alicuius humane rationis apparentia loco, quem tenuerit, dimovere. quare necessarium est neophitis cum fide simul addiscere qua ratione valeant se tueri.

Or quanto la fede ci impone di credere è tale di per sé che la ragione umana non è capace d'intenderlo; di qui la necessità di porgere ai novizi le armi per tutelare la fede loro. (Salutati; Novati 191 I: 223)

Now what faith alone leads us to believe is such that human reason by itself is not capable of understanding; therefore, it is necessary to give novitiates the means to protect their faith through reason.

The ability to speak employing the techniques of ancient rhetoric is the best defense against who speaks falsely, and it is also the most effective way to acquire sacra sapienza. Poetry consists of all the oratorical arts, and since the Sacred 
Scriptures are its maximum expression, poetic writing cannot be contradictory to Christian faith.

While Salutati's reinforcement of the nexus between literary study, which protects against falsehoods, and Christian morality is rooted in the apologetic tradition that typifies the defense of poetry in $14^{\text {th }}$ century writers from Boccaccio to Francesco da Fiano, Pier Paolo Vergerio, in his De ingenius moribus et liberalibus adolseentie studiis, written in about 1403 and generally recognized as the first truly pedagogical treatise, Vergerio theorizes an education aimed at a preparation for secular life. The treatise, the first that deals entirely with education, was written to Ubertinus, the son of Francesco Carrara of Padova and a future political leader. While critics (such as Eugenio Garin) initially situated Vergerio's treatise within the current of writers who advocate for the civic component as the ultimate goal of literary study, Robey has demonstrated that Vergerio's work represents a clear break from the Christian humanist apologetic tradition as it rarely mentions any theological concerns in the text. Instead, the treatise promotes "all branches of pure learning, the literary and the mathematical, the long-established and the relatively new" as being "worthy of pursuit in their own right" (Robey 1980: 47) and sees the "study of letters as a form of rest" and a "pleasant pastime" (Robey 1980: 42) that serves as a respite from public life. While closely following the Petrarchan model of a contemplative life, Vergerio downplays the moral impact of literary study while stressing its value as a protective force against a world that is undergoing heavy social and political upheaval, thereby further secularizing the humanist project. The only means at mankind's disposal to defend against this uncertainty, to deal with it with intelligence and wisdom, is through an appropriate program of humanistic study.

Et quidem quod verum est, litterarum disciplinae neque dementiam adimunt neque malignitatem [...]

To be sure, it is true that the disciplines of letters take away neither madness nor wickedness [...] (Kallendorf 2002: 36-37).

Neque enim opes ullas firmiores aut certiora praesidia vitae parare filis genitores possunt quam si eos exhibeant honestis artibus et liberalibus disciplinis instructos, $[\ldots]$

For parents can provide their children with no more lasting resources, no more dependable protection in life than instruction in honorable arts and liberal disciplines. (Kallendorf 2002: 4-5)

In the wake of Vergerio's De ingenius moribus, and in a different sociopolitical context, successive humanist writers such as Matteo Palmieri (Della vita civile, 1429), Alberti (Della famiglia I433-144I), and Leonardo Bruni (De studiis et litteris) seem more concerned with the utility of the studia humanitatis in the service 
of an active civic life with the goal of shaping good citizens and statesmen capable of resisting the trappings of political power, a component that was not entirely absent even in Vergerio's treatise.

Deberent autem, ut fere dixerim, omnia, nam et publice interest iuventutem in civitatibus bene moratam esse, et si fuerint adulescentes ratione instituti, erit id quidem utile civitatibus et ipsis bonum.

For it is in the public interest that the young people in our cities be wellbehaved, and if our youth are brought up properly, this will be useful indeed to our cities and good for them as well. (Kallendorf 2002: 20-21)

Verum Aristoteles quidem voluit liberalibus scientiis non nimis indulgendum nec immorandum esse ad perfectionem, civilem hominum vitam negotiosamque respectans. Nam qui totus speculationi ac litterarum illecebris deditus est, is est forsitan sibi ipsi carus, at paarum certe utilis urbi aut princeps est aut privatus.

Aristotle, indeed, being concerned with the active, civic life, believed one should not over-indulge in the liberal arts nor linger over them in pursuit of perfection. For someone who dedicates himself completely to theory and the delights of literature perchance becomes dear to himself, but whether a prince or a private citizen, he is surely of little use to his city. (Kallendorf 2002: 5859)

The secularization of the humanist ideal reveals a shift in the concept of virtue, which comes to signify the level of service in public life as a moral obligation rather than that involved in service to God. From both a cultural and religious prospective, this weakening of the metaphysical component in the social life of the individual represents one of the most distinctive elements of this secularization process.

Alberti, in the preface to and in Book One of his Della famiglia (written in dialogue form between 1433 and I44I), continues the emphasis on this world by assigning to mankind the capacity to model his own destiny and to protect against the blows of fortune with virtue, in whose face Fortune is 'invalida e debolissima a rapirci qualunque nostra minima virtù' (invalid and weak to rob us of any small virtue) (Alberti; Romano; Tenenti 1969: 10). This conception of virtue appears to be entirely devoid of metaphysical valence and emerges as the goal of life that is achieved, in part, through the study of letters. Furthermore, the intellectual, for Alberti, is seen as a vehicle between past and present capable of transcending temporal limits because of the ability to converse with the past through dialogue with texts. In the introduction to the English translation of Alberti's Della famiglia, Guido Guarini states:

It [the proper education] must be one which enables him to "hold discourse with other men", as Garin says. This discourse is one which does not 
recognize the limits of time, for if we are to take possession of our humanity, we must be able to communicate with those who came before us and in our turn speak to future generations. Thus the study of letters is the proper study of man. The man of letters is freed from the limitations of the mortal state, for his "experience" is not restricted to a single lifespan, age, or place. The entire experience of mankind becomes his. The opening words of the Preface to Della Famiglia are an expression of this concept (Alberti; Guarino 197I: 14).

While Alberti places the humanistic study of letters on the level of primary importance as a necessity for nobility of spirit, for the cultivation of the human virtues of grace and kindness, and for happiness in life, he privileges the importance of experience and of civic duty, with the family serving as a sort of microcosm of the body politic. Renouncing one's civic responsibility, just like renouncing one's familial responsibility, is an impossibility. In fact, education alone without doing acts of good - public actions of good - is not enough to arrive at being virtuous. The active participation in public life for Alberti takes on as important a role as literary study, which must allow room for political activity.

Né puossi bene averne dottrina solo da' libri muti e oziosi. Conviensi in mezzo alle piazze, entro a' teatri e fra e' privati ridutti averne altra essercitazione e manifesta esperienza. (Alberti; Romano; Tenenti 1969: 278)

It is not the kind of knowledge one can acquire in solitude, from silent and motionless books. One has to learn it in the public marketplace, at the theater, and in people's homes, through another kind of diligence and experience. (Alberti; Watkins 1969: 268)

Although Alberti writes in the context of a privileged social class, namely that of the mercantile aristocracy of Florence, the purely contemplative aspect of the humanist seems to no longer be part of the conception in relation to the study of letters, which, while capable of giving prestige to individuals and families, it appears as a sort of embellishment for mankind. Humanist learning must be validated in the demonstration of acting with sagacity in the public life of one's civitas, and Alberti himself expressed a certain discomfort, as Renee Watkins (1989) and Gur Zak (2014) have discussed, in his own experience with literary study, as expressed in his De commodis litterarum and his Vita.

In the humanist thinkers of the Quattrocento, participation of one's own volition in public life is the condition necessary to validate and valorize the long years of study, thus bestowing upon the scholar a pragmatic component that provides social benefits toward the common good. This phase of humanism - what Hans Baron has termed civic humanism ${ }^{10}$ - is marked by a shift away from

10 Cfr. BARON, Hans, The crisis of the early Italian Renaissance; civic humanism and republican liberty in an age of classicism and tyranny, Princeton: Princeton University Press, 1955. 
Christian ideals through the acceptance of earthly values, resulting in a shift in projection of the figure of the humanist intellectual that is motivated by a myriad of complex social, political, and historical dynamics grounded in the monumental transformations that brought about the passage into the Early Modern Period. Petrarca wrote in an age in which humanist activity was still excluded from the cultural establishment, and in which the concept of earthly fame was still looked upon with disdain by intellectual and religious leaders alike. In the following century, it was no longer necessary to conceal the writer's or artist's pursuit of recognition for their works, and thus humanist writers from Vergerio to Alberti elaborate a pedagogical program for the study of letters also in terms of political and civic contributions to the res publica, and thus the humanist ideal comes to be valued inasmuch as it can be placed into the service of the community. The various theories regarding the role of instruction reveal an ambivalence not only towards a theory for the development of an appropriate educational curriculum but also about the proper framing of the role of knowledge within such a curriculum, a framing that would necessarily direct the objectives of the educational process. These issues necessarily impact, and are in turn impacted by, the conception of the figure of the humanist, whose public role is amplified given the crucial nature of its position in social terms. The entrance of a humanist educational curriculum into the institutional structures of society, most importantly the university system ${ }^{11}$, in the $15^{\text {th }}$ century seems to coincide with the appearance of the word pedante.

\section{Conclusions}

The word pedante begins to appear in the Quattrocento and although it was not necessarily a pejorative term at the time of its first textual usage, over time it acquired the negative connotation associated with the later image of the man of counterfeited education. While its derivation remains somewhat unclear - it's original meaning, according to Battaglia, was "un soldato a piede; un pedone" (a foot soldier) (Battaglia 1995: 917), - pedante in the humanist period first appears in several burlesque sonnets by Burchiello (pseudonym of Domenico di Giovanni, I404- 1449) around the middle of the century with the meaning "colui che guida i fanciulli e insegna loro; pedagogo" (he who guides and teaches young people; pedagogue) (Cortelazzo; Zolli 1985: 897). The character of the pedante will later incorporate connotations of the 'false poet' as described in Ariosto and Berni along with those of the false maestro whose characteristics had been developed over the humanist period as ideally being provided with virtue, ingegno and

\footnotetext{
${ }^{11}$ For a discussion of the relationship between humanism and the Italian university system, cfr. LINES, David, "Humanism and the Italian Universities" in CELENZA, Christopher S.; GouWENS, Kenneth, (eds.), Humanism and Creativity in the Renaissance: Essays in Honor of Ronald G. Witt. Leiden/Boston: Brill, 2006, pp. 327-346.
} 
knowledge. From the objective meaning of the term, writers such as Aretino and Annibale Caro infuse a pejorative connotation defined by Battaglia as: "una figura di educatore a livello elementare, di condizione sociale servile" (the figure of an educator at an elementary level, of a socially servile condition) (Battaglia 1995: 917), and successively the term assumes the following meaning, which derives directly from the character type in Italian Renaissance comic theater:

un letterato semidotto, di cultura incerta e manchevole, di mente ottusa e ristretta, e per contro saccente e presuntuoso, grossolano e ruvido nel tratto sudicio e sciatto nel vestire, non di rado manesco con gli allievi, e contraddistinto sempre dall'uso pomposo di un risibile linguaggio smodatamente infarcito di latinismi spesso scorretti. (Battaglia 1995: 917)

a semi-erudite man of letters, of uncertain and insufficient knowledge, obtuse and narrow-minded, and, in spite of this, arrogant and presumptuous, unrefined and coarse in his features, filthy and careless in his wardrobe, not rarely violent with his students, and always distinguished by the pompous use of a ridiculous language unrestrainedly filled with frequently incorrect Latinisms.

The meaning of the word umanista appears to follow an analogous trajectory during the Cinquecento, even though scholars have encountered difficulty in determining its precise meaning in the $15^{\text {th }}$ and $16^{\text {th }}$ centuries. ${ }^{12}$ Campana and Kristeller agree that the term, which originated in the second half of the $15^{\text {th }}$ century, was used to denote teachers, and later also students, of the studia humanitatis and/or classical literature. By the middle of the $16^{\text {th }}$ century umanisti were being described with traits similar to those of pedants, according to Grendler's study of the few known instances of the word in that period. The connotative parabola of the two terms, based on the sparse textual evidence available, seems to indicate that by 1540 the separation between humanist and pedant was well on its way to disappearing as those practitioners of letters in the volgare, such as Aretino and Francesco Sansovino, did not consider themselves humanists (Grendler 1967: 319). Grendler's successive inquiry concludes that in the second half of the Cinquecento, the term seems to indicate one who held a university teaching position even though his scholarly activities could also include areas outside of the studia humanitatis. In this characterization of the figure, as

12 Cfr. CAMPANA, Augusto, "The Origin of the Word Humanist" in Journal of the Warburg and Courtauld Institutes, 1946, vol. 9, Pp. 60-73; KRISTELLER, Paul, Renaissance Thought: The Classic, Scholastic, and Humanist Strains, New York: Harper, 1961, and his Eight Philosophers of the Renaissance, Stanford, CA: Stanford University Press, 1964; GRENDLER, Paul, "Five Italian Occurrences of Umanista, I540-1574" in Renaissance Quarterly, 1967, vol. 20, no. 3, pp. 317-325 as well as his The Concept of Humanist in Cinquecento Italy, 197I, Dekalb, IL: Northern Illinois University Press, both now in GRENDLER, Paul, Culture and Censorship in Late Renaissance Italy and France, London: Variorum Reprints, I98I, pp. 317-325 and Pp. 447-463. 
Grendler concludes, "The humanists were seen as professional scholars in disciplines unrelated to the active life" (Grendler 1971: 460), causing political leaders to reject the model of the humanist teacher for their own children. The negative conception of the figure, then, results from this perceived exclusion from the pragmatical aspects, above all the participation in civic life, which in the Quattrocento was a principal goal of the man of letters. In this sense, the conception of the figure seems to have returned to the model of Petrarca, without, however, the concern for reconciling the recovery of Latin culture with Christianity. The secularization, then, of the institutionalized humanist education leads to a sort of isolation of knowledge in terms of its inability to be applied to a real-world framework.

The socio-linguistic comparison of these two terms seems to suggest a gradual shift regarding the practical nature of the study of Latin culture, specifically in its ability to respond to the rapid transformations of society between the $15^{\text {th }}$ and $16^{\text {th }}$ centuries. The recovery of lost knowledge that drove the renewal in institutions and practices of learning was no longer held in high esteem by a new generation of cultural and political leaders who viewed the methods and forms of knowledge as impractical, tiresome, and a means of idle refuge from the true challenges of the period, which instead required decisive action. By the early decades of the Cinquecento, the humanist impetus, which had conserved its original character and so pervasively influenced social, political, and religious institutions, had by then consumed its capacity to affront new cultural and historical realities, not least of which was the expansion of the print-culture industry. Therefore, pedants, who came to be associated with Latin learning along with many other unflattering traits that were diffused through their numerous theatrical representations, were deeply ensconced in the society that succeeded in both promoting them and ridiculing them at the same time, thereby becoming, as Graf puts it, "una negazione vivente degli amori e delle aspirazioni de' tempi, non poteva non attirar su di sè l'odio e la derisione" (a living negation of the loves and aspirations of the time, unable to not attract hatred and derision) (Graf I888: 193). Pedants are direct products of professionalized Humanism as they embody the earliest ideological principles of the movement, and thus the figure itself is seen as a site of crisis for classical education that takes place within the context of the ideological, historical, religious, and cultural clashes that define the Cinquecento. It was the humanist recovery itself that brought forth the conception of mankind's own earthly dignitas together with the recognition of its own earthly limitations, and the theatrical version of the pedant seems to reflect the very same cultural contradictions that characterized the development of the humanist movement. 


\section{Bibliographical references}

Alberti, L. B.; Romano, R.; Tenenti, A. (1969) (eds.). I Libri della Famiglia. Torino: Einaudi.

AlBeRTI, L. B.; WATKINS, R. N. (1969) (trans. and intro.). The Family in Renaissance Florence. Columbia, SC: University of South Carolina Press.

AlBeRTI, L. B.; GUARINO, G. (I97I) (trans, intro, and notes). The Albertis of Florence: Leon Battista Alberti's Della Famiglia. Lewisburg: Bucknell University Press.

ArIosto, L.; WIGGINS, P. D. (1976) (trans.). The Satires of Ludovico Ariosto: A Renaissance Autobiography. Athens: University of Ohio Press.

BaratTo, M. (1964). Tre saggi sul teatro. Venice: Neri Pozza.

BARON, H. (1955). The crisis of the early Italian Renaissance: Civic Humanism and Republican Liberty in an Age of Classicism and Tyranny, Princeton: Princeton University Press.

BATtAGLIA, S. (1995). Grande dizionario della lingua italiana. Vol. XII. Turin: Unione Tipografico Editore Torinese.

Bernardo, A. (1986). Petrarch's Autobiography: Circularity Revisited (In memory of Charles S. Singleton), Annali d'Italianistica 4, 45-72.

BeRNI, F.; ROMEI, D. (I985) (ed.). , Rime. Milan: Mursia, 1985.

CAIRNS, Ch. (1985). Pietro Aretino and the Republic of Venice. Florence: Leo S. Olschki Editore.

CAMpanelul, A. (1965). II dottor Balanzone. Bologna: Patron.

CAStiglione, B.; BARBeRIS, W. (1998) (ed.). Il libro del Cortegiano. Turin: Einaudi.

CORSARO, A. (I988). Il poeta e l'eretico. Florence: Le Lettere, 1988.

CORTELAZZO, M.; Zolli, P. ( 1985). Dizionario etimologico della lingua italiana. Bologna: Zanichelli.

ENeNKEL, K. (1998). Modelling the Humanist: Petrarch's Letter to Posterity and Boccaccio's Biography of the Poet Laureate. In ENENKEL, K.; DEJONGCrANe, B.; LIEBREGTS, P. (eds.), Modelling the Individual: Biography and Portrait in the Renaissance. Amsterdam/Atlanta: Rodopi, I I-49.

(2003). In Search of Fame: Self-Representation in Neo-Latin Humanism. In GeRSH, S.; ROEST, B. (eds.), Medieval and Renaissance Humanism: Rhetoric, Representation and Reform. Leiden/Boston: Brill, 93-1/3.

Figorillo, M. C. (2008). Meglio ignorante che dotto: l'elogio paradossale in prosa nel Cinquecento. Naples: Liguori.

GARIN, E. (1958). Il pensiero pedagogico dello Umanesimo. Florence: Giuntine-Sansoni. GRAF, A. (I888). I pedanti. Attraverso il Cinquecento, Torino: Loescher, I7I-2I3.

GRENDLER, P. (1967). Five Italian Occurrences of Umanista, I540-1574. Renaissance Quarterly 20 (3), 317-325.

(197I). The Concept of Humanist in Cinquecento Italy. Dekalb, IL: Northern Illinois University Press. 
HaNSEN, M. (20I4). After the Veronica: Crisis and the Ars sacra of Polidoro da Caravaggio and Pontormo. I Tatti Studies in the Italian Renaissance 17 (2), 325-367.

Hodgart, A. B. (1997). Giordano Bruno's The Candle-Bearer: An Enigmatic Renaissance Play. Lewiston/Queenston/Lampeter: The Edwin Mellen Press.

Kallendorf, C. W. (2002) (ed. and trans.). Humanist Educational Treatises. Cambridge: Harvard University Press.

KRISTELleR, P. (196I). Renaissance Thought: The Classic, Scholastic, and Humanist Strains, New York: Harper.

(1964). Eight Philosophers of the Renaissance, Stanford, CA: Stanford University Press.

LINES, D. (2006). Humanism and the Italian Universities. In CelenZA, Ch. S.; GouWENS, K., (eds.), Humanism and Creativity in the Renaissance: Essays in Honor of Ronald G. Witt. Leiden/Boston: Brill, 327-346.

Mazzotta, G. (1993). The Worlds of Petrarch. Durham/London: Duke University Press.

Nigro, R. (2002) (ed. and intro.). Burchiello e burleschi. Rome: Istituto poligrafico e Zecca dello Stato.

Petrarca, F. ; Fenzl, Enrico (ed.) (1999). De ignorantia: Della mia ignoranza e di quella di molti altri. Milano: Mursia.

ReynoldS, A. (1988). The Poet in Society: Francesco Berni and Court Life in Cinquecento Rome. Spunti e Ricerche 4-5, 5I-62.

ReYNoldS, A.; BerNI, F. (I 997). Renaissance Humanism at the Court of Clement VII: Francesco Berni's Dialogue Against Poets in Context. New York: Garland Publishing.

ROBEY, D. (1980). Humanism and Education in the Early Quattrocento: the De ingenuis moribus of P. P. Vergerio. Bibliotèque d'Umanisme et Renaissance 42 (I), 27-58

SalutATI, C.; NovatI, F. (ed.) (I89|-19|I). Epistolario Di Coluccio Salutati. Vol. 4. Rome: Forzani E C., Tipografi del Senato.

StÄUble, A. (I99|). «Parlar per lettera»: il pedante nella commedia del Cinquecento e altri saggi sul teatro rinascimentale. Rome: Bulzoni Editore.

WATKINS, R. (1989). L.B. Alberti in the Mirror: An Interpretation of the Vita with a New Translation. Italian Quarterly. 30 (I I7), 5 - 30.

WITT, R. G. (2000). 'In the Footsteps of the Ancients': The Origins of Humanism from Lovato to Bruni. Leiden/Boston/Köln, Brill.

ZAK, G. (20I4). Humanism as a Way of Life: Leon Battista Alberti and the Legacy of Petrarch. I Tatti Studies in the Italian Renaissance. 17 (2), 2I 7-240. 
